\title{
Dormancy-breaking Method Effects on Azalea Longevity
}

\author{
Lori A. Black, Terril A. Nell, and James E. Barrett \\ Ornamental Horticulture Department, University of Florida, Gainesville, \\ FL 32611
}

Additional index words. postharvest, gibberellic acid

Applications of gibberellic acid (GA) have been shown to break bud dormancy on various azalea cultivars (Furuta and Straiton, 1966; Larson and Sydnor, 1971; Nell and Larson, 1974; Joiner et al., 1982/83). No studies have been reported on the effects of GA on postproduction performance. This research was conducted to evaluate the effect of cold and GA on the breaking of bud dormancy and postproduction performance and longevity of 'Gloria' azalea (Rhododendron sp.).

Dormant-budded 'Gloria' azaleas with an 18- to $23-\mathrm{cm}$ crown diameter in $15-\mathrm{cm}(1.6$ liters) pots were obtained from a commercial grower (Yoder Brothers, Alva, Fla.). After the dormancy-breaking treatment, plants were placed in a fiberglass greenhouse with fan and pad cooling. The greenhouse ranged from a maximum day of $35 \mathrm{C}$ to a minimum night of 16C. Plants were watered daily with tap water and no fertilizer was applied. When eight individual flowers were open on each plant, it was moved to an interior room (21 $\pm 1 \mathrm{C}$ and $50 \% \pm 5 \% \mathrm{RH}$, with 12 $\mu \mathrm{mol} \cdot \mathrm{s}^{-1} \cdot \mathrm{m}^{-2}$ of irradiance, $12 \mathrm{hr}$ daily, from cool-white fluorescent lamps) to evaluate postharvest performance.

One group of plants received 4 weeks of cold $\left(2 \pm 0.5 \mathrm{C}\right.$ with $15 \mu \mathrm{mol} \cdot \mathrm{s}^{-1} \cdot \mathrm{m}^{-2}$ of irradiance, $12 \mathrm{hr}$ daily, from cool-white flourescent lamps) to break dormancy and then was given foliar sprays of $\mathrm{GA}_{4,7}$ at 500 $\mathrm{mg} \cdot \mathrm{liter}^{-1}$ on days 3, 10, and 17 after removal from the cooler. Preliminary research confirmed that 'Gloria' azaleas placed at $2 \mathrm{C}$ for 4 weeks with no GA to break bud dormancy had poor flowering uniformity. A second group received 6 weeks of cold and no GA. The-experimental design was a randomized complete block with four plants per experimental unit and three replications. Data were tested by analysis of variance and Tukey's honestly significant difference test.

Number of days from the time plants were placed in cold treatment until eight individual flowers were open was recorded as days to harvest. For production and postproduction evaluations, buds or flowers were grouped: 1) tight, buds with no flower color

Received for publitation 9 Nov. 1989. Florida Agr. J. Ser. no. R-00235. We are grateful to American Floral Endowment for support of this project and to Yoder Brothers for the plants used in this-study. The cost of publishing this paper was defrayed in part by the payment of page charges. Under postal regulations, this paper therefore must be hereby marked advertisement solely to indicate this fact. showing: 2) showing color, buds exhibiting flower color up to $2.5 \mathrm{~cm}$; 3) candles, buds with at least $3 \mathrm{~cm}$ of flower color showing; and 4) open flowers, diameter $\geq 3 \mathrm{~cm}$. The number in each category was determined at harvest and after 2 weeks at 21C. Dormancybreaking treatments were applied after flower bud set, so the total number of flowers or buds were not affected by treatments. Postproduction longevity was determined as days from harvest to when $90 \%$ to $95 \%$ of all flowers showed signs of necrosis.

Open-flower diameter was recorded at harvest. Buds showing 2.0 to $2.5 \mathrm{~cm}$ of flower color at harvest were tagged and flower diameter recorded after 2 weeks at 21C. Four flowers per plant were used to determine the diameters of open flowers and of buds that opened at $21 \mathrm{C}$

At harvest and after 2 weeks at 21C, flower color of the adaxial surface of petals, void of red spots, was determined with a HunterLAB colorquest sphere spectrocolorimeter (Hunter Assoc. Lab, Reston, Vs.) using ' $L$ ' and 'a' modes. A flower petal with an intense pink color would have a low ' $L$ ' value and a high positive 'a' value. One petal from each of four flowers per plant was used for a total of 48 petals per treatment to determine flower color.

Cold plus GA-treated plants flowered sooner than did plants given 6 weeks cold and no GA (Table 1). This has also been noted in other azalea cultivars (Furuta and Straiton, 1966; Nell and Larson, 1974; Joiner et al., $1982 / 83$ ). Postharvest longevity was $\approx 10 \%$ less for cold plus GA-treated plants (Table $1)$.
At harvest, the number of flowers/buds in each stage were not affected by dormancybreaking method (data not shown). After 2 weeks at $21 \mathrm{C}$, the number of buds showing color and of tight buds were not significantly different due to treatment (data not shown). However, for the plants given 6 weeks of cold, more buds in the candle stage developed to the open-flower stage than did those of plants given cold plus GA (Table 1). Thus, after 2 weeks at $21 \mathrm{C}$, there were more open flowers on plants held cold for 6 weeks.

The ' $L$ ' value $(100=$ white and $0=$ black) for flower color at harvest was slightly less for cold plus GA-treated plants (Table 1), indicating that flower color was darker. Redness of the flower ('a' value) was not affected by treatment (data not shown). Openflower diameter was greater for cold plus GA-treated plants at harvest (Table 1). Buds showing 2.0 to $2.5 \mathrm{~cm}$ of color at harvest and that then opened at $21 \mathrm{C}$ were larger on plants following 6 weeks of cold than on plants held in the 4-week cold plus GA treatment (Table 1).

These results demonstrate advantages in both methods of breaking flower bud dormancy in 'Gloria' azalea. The advantages of the 6-week cold treatment with no GA are: 1) increased postharvest longevity; 2) increased number of buds in the open-flower stage after 2 weeks at $21 \mathrm{C}$; and 3 ) larger flower diameter of flowers that developed in the interior. The advantage for the 4-week cold plus GA treatment is less cooler and production time.

\section{Literature Cited}

Furuta, T. and T.H. Straiton, Jr. 1966. Synergism of kinetin and gibberellic acid in flowering of unchilled azalea, cultivar Red Wing. Proc. Amer. Soc. Hort. Sci 88:591-594.

Joiner, J. N., O. Washington, C.R. Johnson, and T.A Nell. 1982/83. Effect of exogenous growth regulators on flowering and cytokinin levels in azaleas. Scientia Hort. 18:143-151.

Larson, R.A. and T.D. Sydnor. 1971. Azalea flower bud development and dormancy as influenced by temperature and gibberellic acid. J. Amer. Soc. Hort. Sci. 96:786-788.

Nell, T.A. and R.A. Larson. 1974. The influence of foliar application of $\mathrm{GA}_{3}, \mathrm{GA}_{4}$, and $\mathrm{PBA}$ on breaking flower bud dormancy on azalea cvs Redwing and Dogwood. J. Hort. Sci. 49:323-328.

Table 1. The effects of two methods of breaking bud dormancy of 'Gloria' azalea on production time, flower development, and postharvest longevity.

\begin{tabular}{|c|c|c|c|c|c|c|c|c|c|}
\hline \multirow{2}{*}{\multicolumn{2}{|c|}{$\begin{array}{c}\text { Dormancy- } \\
\text { breaking method } \\
\end{array}$}} & \multirow[b]{3}{*}{$\begin{array}{c}\text { Days } \\
\text { harvest }\end{array}$} & \multirow[b]{3}{*}{$\begin{array}{c}\text { Postharvest } \\
\text { to } \begin{array}{c}\text { longevity } \\
\text { (days) }\end{array} \\
\end{array}$} & \multirow{2}{*}{\multicolumn{2}{|c|}{ Data at harvest' }} & \multicolumn{4}{|c|}{ Data after 2 weeks at $21 \mathrm{C}^{\mathrm{w}}$} \\
\hline & & & & & & \multirow[b]{2}{*}{$\begin{array}{c}\text { No. } \\
\text { open } \\
\text { flowers }\end{array}$} & \multirow[b]{2}{*}{$\begin{array}{l}\text { No. } \\
\text { candles }\end{array}$} & \multirow[b]{2}{*}{$\begin{array}{c}\text { 'L' } \\
\text { value }\end{array}$} & \multirow{2}{*}{$\begin{array}{c}\text { Diam of } \\
\text { flowers that } \\
\text { opened in rooms } \\
(\mathrm{cm})\end{array}$} \\
\hline $\begin{array}{l}\text { Cold }^{2} \\
\text { (weeks) } \\
\end{array}$ & $\mathrm{GA}_{4,7}{ }^{y}$ & & & $\begin{array}{l}\text { Open flower } \\
\text { diam } \\
(\mathrm{cm})\end{array}$ & $\begin{array}{c}\text { 'L' } \\
\text { value }\end{array}$ & & & & \\
\hline 4 & Yes & 67 & 22 & 7.6 & 56.0 & 32 & 20 & 58.0 & 3.4 \\
\hline 6 & No & '78 & 24 & 7.0 & 57.1 & 44 & 13 & 59.1 & 4 \\
\hline $\mathrm{HS} \mathrm{D}_{0.05}$ & & 3 & 1 & 0.3 & 0.6 & 6 & 5 & 0.7 & 0.8 \\
\hline $\mathrm{HS} \mathrm{D}_{0.01}$ & & 4 & 1 & 0.4 & 0.8 & 8 & NS & 0.9 & 1.1 \\
\hline
\end{tabular}

${ }^{2}$ Temperature maintained at $2 \pm 0.5 \mathrm{C}$ with $15 \mu \mathrm{mol} \cdot \mathrm{s}^{-1} \cdot \mathrm{m}^{-2}$ of irradiance, $12 \mathrm{hr}$ daily, from coolwhite fluorescent lamps.

${ }^{y} \mathrm{GA}$ was applied at $500 \mathrm{mg} \cdot \mathrm{liter}^{-1}$ to plants as a foliar spray, after cold treatment, on days 3,10 , and 17.

${ }^{x}$ Days to eight individual flowers open from the day plants were placed in cold treatment.

"Twelve hours of irradiance at $12 \mu \mathrm{mol} \cdot \mathrm{s}^{-1} \cdot \mathrm{m}^{-2}$ provided daily by cool-white fluorescent lamps; $50 \%$ $\pm 5 \%$ RH.

${ }^{\mathrm{NS}}$ Nonsignificant. 